\title{
ЗМІНИ ВАРІАБЕЛЬНОСТІ СЕРЦЕВОГО РИТМУ У ДІТЕЙ МОЛОДШОГО ШКІЛЬНОГО ВІКУ З ЙОДОДЕФІЦИТОМ ВПРОДОВЖ НАВЧАЛЬНОГО POKY
}

\author{
ДВНЗ «Тернопільський державний медичний університет імені І.Я. Горбачевського МОЗ України»
}

\begin{abstract}
Мета - вивчення впродовж навчального року функціонального стану автономної нервової системи у дітей молодшого шкільного віку з йододефіцитом.

Матеріали і методи. Обстежено 239 дітей віком 6-10 років. Визначали йод в сечі та варіабельність серцевого ритму.

Результати. У кінці навчального року, порівняно із початком, в учнів 1-го класу, забезпечених йодом, спостерігалося зниження показника адекватності процесів регуляції на $11 \%(p<0,05)$, відношення індексу напруження в пробі до індексу напруження в фоновій пробі - на 38\% $(\mathrm{p}<0,05)$. В учнів 2-го класу 3 йододефіцитом спостерігалося підвищення амплітуди моди на 21\% (p<0,05), показник адекватності процесів регуляції - на 26\% $(p<0,05)$, індекс напруження - на 56\% ( $<0,05)$. У четвертокласників спостерігалось підвищення показників індексу напруження на $28 \%(p<0,05)$ та зниження середньоквадратичного відхилення на $37 \%(p<0,05)$.
\end{abstract}

Висновки. Встановлено, що у дітей з дефріцитом йоду переважає симпатичний вплив автономної нервової системи.

КЛЮЧОВІ СЛОВА: варіабельність серцевого ритму, автономна нервова регуляція, діти, йододефіцит.

Систему кровообігу можна розглядати як чутливий індикатор адаптаційних реакцій цілісного організму [2], а варіабельність серцевого ритму (ВСР) добре відображає ступінь напруження регуляторних систем, обумовлених активацією системи гіпофіз-наднирники і реакцією симпатоадреналової системи, що виникає у відповідь на будь-яку дію стресових чинників.

Мета дослідження - вивчення впродовж навчального року функціонального стану автономної нервової системи (АНС) у дітей молодшого шкільного віку з йододефіцитом.

Матеріали і методи. Обстежено 239 дітей віком 6-10 років. Вивчення ВСР здійснювали за допомогою приладу комплексної комп'ютерної діагностики "Полі-Спектр" виробництва компанії "Нейрософт". Запис кардіоінтервалограми проводився протягом п'яти хвилин у лежачому положенні, і після переходу у вертикальне - шість хвилин. Обстежували дітей на початку, в середині та у кінці навчального року $[1 ; 5]$. У своїй роботі ми враховували в горизонтальному (фонова проба (ф)) і вертикальному (ортостатична проба (о)) положенні такі показники: середня частота серцевих скорочень (ЧСС), середнє арифрметичне значення інтервалу R-R(M), середньоквадратичне відхилення (СК), моди (Мо), амплітуди моди (АМо), медіанне значення інтервалу R-R (Me), варіаційний розмах (BP), індекс вегетативної рівноваги (IBP), показник адекватності процесів регуляції (ПАПР), вегетативний показник

(с) О.М. Юрчишин, О.Є. Копач, Г. А. Крицька, 2015 ритму (ВПР), індекс напруження (IH), відношення індексу напруження в пробі до індексу напруження в фооновій пробі $\left(\mathrm{IH}_{2} / \mathrm{IH}_{1}\right)$, приріст ЧСС в ортостатичній пробі [3;4;5]. Отриманий цифровий матеріал обробляли методом варіаційної статистики за Стьюдентом 3 використанням пакету програм Statistica 6.0. Також застосовували непараметричні методи (Манна-Уітні), $\mathrm{P}(\mathrm{u})=0,05$. Для визначення йодурії у дітей досліджували рівень екскреції йоду у разових порціях сечі методом I. Dunn et al. [6], пальпували щитоподібну залозу.

Результати дослідження та їх обговорення. За результатами ВСР в учнів 1-го класу із десріцитом йоду (ДЙ) на початку навчального року встановлено суттєво менше значення показників ЧССо, IBPф - на 37\% (p<0,05), IHфр - на 39\% $(p<0,05)$ та вище Моо - на 3\% щодо аналогічних показників у дітей контрольної групи. У середині навчального року у дітей із дй спостерігалося вірогідно менше значення величини IHф - на 36\% щодо контрольних даних.

Аналіз динаміки показників впродовж навчального року показав, що у першокласників 3 нормальним вмістом йоду у сечі у кінці навчального року порівняно із серединою спостерігалося підвищення СКо на $18 \%(p<0,05)$, ВРо - на $44 \%(p<0,05)$, BPсp - на $60 \%(p<0,05)$ та зниження IBPo на $12 \%$, ВПРо - на 14\% $(p<0,05)$, IHо - на 14\% $(p<0,05)$, а також тенденція до підвищення СКф.

У кінці навчального року порівняно із початком у першокласників, забезпечених йодом, спостерігалося зниження ЧССф на 4\% $(p<0,05)$, ПАПРфр - 
на $11 \%(\mathrm{p}<0,05), \mathrm{IH}_{2} / \mathrm{IH}_{1}-$ на $38 \%(\mathrm{p}<0,05)$. Такі зміни відбувалися на тлі збільшення Мфр на 5\%, Мофрна 5\%, Меф - на 5\% $(\mathrm{p}<0,05)$.

У першокласників із йододефріцитом у середині навчального року, порівняно 3 його початком, спостерігалося достовірне зниження ВРфр на 46\%. У кінці навчального року достовірних відмінностей порівняно з серединою у показниках не спостерігалося. У кінці навчального року у школярів цієї групи виявили достовірне зниження порівняно 3 початком ВРф - на $52 \%$.

У другокласників з дЙ на початку навчального року встановлено нижчі величини IBPф - на 44\% $(p<0,05)$, ІНф - на 45\% ( $p<0,05)$ щодо аналогічних показників у контрольній групі дітей цієї ж вікової категорії. У середині навчального року у другокласників із дй спостерігалися достовірно менші значення величин ПАПРо - на 13\%, АМоо - на $13 \%$ та суттєве збільшення ВРо (майже удвічі), а також намітилась тенденція до підвищення СКо порівняно із здоровими однолітками. За таких умов спостерігали зменшення показника $\mathrm{IH}_{2} / \mathrm{IH}_{1}$ на $50 \%$ $(p<0,05)$ у дітей із дй. У кінці навчального року виявили зниження показників Меф на $60 \%(p<0,05)$, Мео - на 72\% (p<0,05), $\mathrm{IH}_{2} / \mathrm{IH}_{1}-$ на 68\% $(\mathrm{p}<0,05)$ та тенденцію до підвищення ІНо.

В учнів 2-го класу з нормальним вмістом йоду у середині навчального року спостерігалося зниження Мо на 5\% (p<0,05), Моо - на 5\% (p<0,05), Мео на $3 \%$ порівняно 3 його початком. У кінці навчального року порівняно із серединою у дітей дослідної та контрольної груп розбіжностей у вивчених показниках не спостерігалося. У кінці навчального року, порівняно з початком, у другокласників, які були належним чином забезпечені йодом, спостерігалося підвищення Мефр на 58\% $(p<0,05)$, Мео на $71 \%(p<0,05), \mathrm{IH}_{2} / \mathrm{IH}_{1}-$ на $56 \%(\mathrm{p}<0,05)$.

В учнів 2-го класу з ДЙ в середині навчального року, порівняно $з$ його початком, спостерігалося зниження $\mathrm{IH}_{2} / \mathrm{IH}_{1}$ на $47 \%(\mathrm{p}<0,05)$. У кінці навчального року порівняно із серединою у них виявили підвищення IBPо на 53\% ( $p<0,05)$, IHо - на 56\% $(p<0,05)$ та тенденцію до зниження ВРо.

У кінці навчального року порівняно з початком в учнів 2-го класу з дй спостерігалося підвищення AMoор на 21\% (p<0,05), ПАПРфр - на 26\% (p<0,05), IHср - на 56\% (p<0,05) та вірогідне зниження Мефрна 7\%, а також намітилась тенденція до підвищення IBPф. Аналогічна тенденція спостерігалась при порівнянні даних на кінець навчального року порівняно із його початком.
У третьокласників з дЙ на початку та у середині навчального року достовірних відмінностей у вивчених показниках ВСР порівняно із здоровими однолітками не виявлено. У кінці навчального року спостерегли достовірне зниження показника Моф на $6 \%$ щодо контролю.

В учнів 3-го класу з нормальним вмістом йоду в сечі у середині навчального року порівняно з його початком достовірних відмінностей між показниками не спостерігалося. У кінці навчального року порівняно з серединою у них встановлено вірогідне зниження ЧССо - на 4\%, АМоо - на 13\% та підвищення Мо - на 3\%, Мео - на 5\%. У кінці навчального року порівняно з початком у третьокласників, які належним чином забезпечені йодом, вірогідних розбіжностей у показниках не виявлено.

В учнів 3-го класу з ДЙ протягом року не виявлено достовірних відмінностей у показниках, що вивчалися. У кінці навчального року порівняно з початком у дітей цієї групи виявили підвищення чССф на 5\% $(p<0,05)$ та зниження Мфр на 5\% $(p<0,05)$, Мофр - на $6 \%(p<0,05)$, Меср - на 7\% $(p<0,05)$.

В учнів 4-их класів із дЙ порівняно з дітьми, які забезпечені йодом належним чином, на початку, у середині та у кінці навчального року достовірних відмінностей показників ВСР, які вивчались, не виявлено.

В учнів 4-го класу, які належним чином забезпечені йодом, протягом навчального року не виявлено достовірних відмінностей у рівнях показників, що вивчалися.

В учнів 4-го класу 3 Дй у середині навчального року не встановлено достовірних відмінностей порівняно з його початком. У цих же школярів спостерігалося суттєве підвищення показників ІНо (на 28\%) та зниження СКо на 37\% і тенденція до зниження ВРо у кінці навчального року порівняно з його серединою. Водночас у четвертокласників із дЙ достовірних відмінностей між показниками у кінці навчального року щодо його початку не встановлено.

\section{Висновки}

На основі аналізу ВСР спостерігаються суттєві розбіжності вивчених показників у дітей із дЙ та у школярів, які належним чином забезпечені йодом.

Встановлено вірогідні зміни між показниками в межах дослідної на контрольної груп впродовж навчального року. При цьому необхідно акцентувати, що у дітей із ДЙ показники ВСР зазнавали більш виразних змін, ніж у здорових однолітків.

Перспективи подальших досліджень полягають у подальшому спостережені та вивченні зміни варіабельності серцевого ритму у школярів для оптимізації профрілактики у дітей з дефіцитом йоду.

\section{Список літератури}

1. Адаптационный ресурс и вегетативная дисорункция детей различных возрастных групп / Н. Г. Гулевская, Ю. А. Татаренко, М. Г. Шаблий [и др.] // Тези І Конгрессу федерації педіатрів країн СНД «Дитина і суспільство: проблеми здоровя, розвитку та харчування» // Педіатрія, акушерство та гінекологія. - 2009. - № 3. - С. 43. 
2. Бабко С. В. Адаптационные возможности и состояние здоровья детей, оставшихся без попечения родителей / С. В. Бабко, С. Н. Бениова // Гигиена и санитария. - 2011. - № 1.- С. 78-80.

3. Баевский Р. М. Оценка адаптационных возможностей организма и риска развития заболеваний [Электронный ресурс] / Р. М. Баевский, А. П. Берсенева. - Режим доступа: http://www.ecg.ru/book02/content.html

4. Баранов А. А. Изучение качества жизни детей - важнейшая задача современной педиатрии / А. А. Баранов, В. Ю. Альбицкий // Российский педиатр. журн. - 2005. - № 5. - С. 30-34.

5. Михайлов В. М. Вариабельность ритма сердца. Опыт практического применения метода / В. М. Михайлов. Иваново, 2008. - 200 с.

6. Dunn J. Two simple metods for measuring iodine in urine / J. Dunn, H. Grutchfield, R. Gutekunst // Thyroid. - 1993. Vol. 3 - P. 119-123.

\title{
ИЗМЕНЕНИЕ ВАРИАБЕЛЬНОСТИ СЕРДЕЧНОГО РИТМА У ДЕТЕЙ МЛАДШЕГО ШКОЛЬНОГО ВОЗРАСТА С ЙОДОДЕФИЦИТОМ В ТЕЧЕНИЕ УЧЕБНОГО ГОДА \\ О.М. Юрчишин, А.Э. Копач, Г.А. Крицкая \\ ГВУЗ «Тернопольский государственный медицинский университет имени И.Я. Горбачевского МЗ Украины»
}

\begin{abstract}
Цель - изучение в течение учебного года функционального состояния автономной нервной системы у детей младшего школьного возраста с йододефицитом.

Материалы и методы. Обследовано 239 детей 6-10 лет. Определяли йод в моче и вариабельность сердечного ритма.

Результаты. В конце учебного года по сравнению с началом у учеников 1-го класса, обеспеченных йодом, наблюдалось снижение показателя адекватности процессов регуляции на $11 \%(p<0,05)$, отношение индекса напряжения в пробе к напряжению в фоновой пробе - на $38 \%(p<0,05)$. У учеников 2-го класса с йододефицитом наблюдалось повышение амплитуды моды на $21 \%(p<0,05)$, показателя адекватности процессов регуляции - на 26\% ( $<<0,05)$, индекса напряжения - на 56\% ( $<<0,05)$. У четвероклассников наблюдалось повышение показателей индекса напряжения на $+28 \%(p<0,05)$ и снижение среднего отклонения на $37 \%(p<0,05)$.
\end{abstract}

Выводы. Установлено, что у детей с дефицитом йода преобладает симпатическое влияние автономной нервной системы.

КЛЮЧЕВЫЕ СЛОВА: вариабельность сердечного ритма, автономная нервная регуляция, дети, йододефицит.

\section{CHANGE OF HEART RATE VARIABILITY IN CHILDREN YOUNGER THAN SCHOOL ADE IODINE DEFICIENCY OF THE ACADEMIC YEAR \\ O.M. Yurchyshyn, O.Ye. Kopach, G.A. Kritska \\ SHEI «Ternopil State Medical University by I.Ya Horbachevsky of MPH of Ukraine»}

Purpose: study during the school year at the autonomic nervous system functional state primary school children from iodine deficiency.

Materials and methods. The study involved 239 children aged 6-10 years. We determined the iodine in urine and heart rate variability.

Results. At the end of the school year, compared to the beginning, children of class 1 secured iodine index decreased adequacy regulation processes by $11 \%(p<0,05)$, relationship stress index in the sample to the index in the background stress test at $38 \%(p<0,05)$. Children in class 2 with iodine deficiency observed increase amplitude of fashion for $21 \%(p<0,05)$, an indicator of the adequacy of regulation processes by $26 \%(p<0,05)$, stress index by $56 \%(p<0,05)$. In fourth-observed performance index increase tension by $28 \%(p<0,05)$ and reduction of the standard deviation of $37 \%(p<0,05)$.

Conclusions/ Found that in children with iodine deficiency prevails sympatyc effect autonomic nervous system.

KEY WORDS: heart rate variability, autonomic nervous regulation, children, iodine deficiency.

Рукопис надійшов у редакцію 28.10.2015 р.

\section{Відомості про авторів:}

Юрчишин Оксана Михайлівна - к.мед.н., асистент кафедри загальної гігієни та екології ДнВЗ "Тернопільський державний медичний університет імені І.Я. Горбачевського МО3 України"; тел.: +38(0352)52-47-88.

Копач Олександра Євгенівна - к.мед.н., асистент кафедри загальної гігієни та екології ДНВЗ "Тернопільський державний медичний університет імені І.Я. Горбачевського МОЗ України”; ттел.: +38(0352)52-47-88.

Крицька Галина Анатоліївна - к.мед.н., доцент кафедри загальної гігієни та екології ДНВЗ "Тернопільський державний медичний університет імені І.Я.Горбачевського МО3 України"; тел.: +38(0352)52-47-88. 